\title{
STUDY OF THE TECHNOLOGY OF STRENGTHENING REINFORCED CONCRETE COLUMNS BY EXTERNAL REINFORCEMENT
}

Molodid O. S.

\section{INTRODUCTION}

In the process of inspecting buildings and constructions, the technical state of the building constructions and of the building as a whole is diagnosed. Further, this work must result in the conclusions on the state of the building constructions and sound recommendations on the technical maintenance of the object and the measures to restore operating properties of the building construction and the object as a whole ${ }^{1}$.

Specialists from the State Enterprise "V.S. Balitsky Research Institute of Building Production" (SE "RIBP") continuously conduct technical inspections of buildings and constructions of various categories of complexity. In case non-typical damages are detected, or typical solutions for repair and restoration works ${ }^{2}$ cannot be used to solve a particular task, or there is a possibility to carry out repair and restoration works in a number of ways, the divisions of the SE "RIBP" apply a scientific and research approach to the solve the tasks at hand. In particular, if the Institute's scientific divisions need to solve a design and technology task, they first conduct theoretical research, which includes the development of scientific research program, program modelling of the work of the construction or the whole building in real-life conditions, plotting dependences etc. Further, as needed, laboratory, iron bird (bed) and field tests with the modelling of the work of the repaired or restored construction or whole building in real-life conditions. If there is a possibility to conduct repair and restoration works in several ways, the Institute's scientists research technical and economic parameters (value, duration and labor intensity of works, cost of the

${ }^{1}$ ДСТУ-Н Б В.1.2-18:2016 Настанова щодо обстеження будівель і споруд для визначення та оцінки їх технічного стану. - Київ: ДП «УкрНДНЦ», 2017. - 47 с.; Методические указания по обследованию фундаментов турбоагрегатов: РД 34.21.323-95. - М.: РАО «ЕЭС России», 1995. $-32 \mathrm{c}$.

${ }^{2}$ ДСТУ Б В.3.1-2:2016. Ремонт і підсилення несучих і огороджувальних будівельних конструкцій та основ будівель і споруд [Чинний від 2017-04-01]. - Київ: ДП «УкрНДНЦ», 2017. - 72 с.; 4. Беляков Ю. И. Романушко Е. Г. Запорожченко С. А. Средства механизации при реконструкции промышленных предприятий / Беляков Ю. И. Романушко Е. Г. Запорожченко С. А. - К.: Будівельник, 1987. - 144 с. 
materials, machines, mechanisms and other equipment necessary for a given technology etc.) of conducting the works using various methods and give recommendations as to the optimal design and technology solution for the operations.

\section{Minsk CHP-3 inspection}

The proposed research and scientific approach was used during a routine inspection of a complex building object, namely Minsk heat and power station (HPS) No. 3. The inspection was initiated by the staff of Minsk HPS No.3 branch, who noticed increased vibration on the pedestal of turbinegenerator PT $-60-130-13$ at station No.5. The vibration test showed that the maximum recorded vibration level reached $6.8 \mathrm{~mm} / \mathrm{sec}$, while the specification vibration level must not exceed $4.5 \mathrm{~mm} / \mathrm{sec}$. The specialists of the OJSC "Belenergoremnaladka" established that the higher-than-normal vibrational oscillations are created due to the deformability of the foundation structures, which is connected with its long-lasting operation (58 years).

As a construction, the foundation is a monolith frame system consisting of five interconnected frames and 8 ribs, and a common base slab. The foundation dimensions of in the plan are $24.5 \times 6 \mathrm{~m}$ (fig. 1). The height of the foundation is $10.8 \mathrm{~m}$. The top of the maintenance platform is $+7.0 \mathrm{~m}$, the top of the base slab $-3.8 \mathrm{~m}$.

Each separate frame of the foundation, with the height of $10.8 \mathrm{~m}$, is formed of two vertical elements (columns or piers) divided in two, in some places in three, tiers by floor slaps $200 \mathrm{~mm}$ in thickness, and united by a beam in the upper part into a common construction. The cross-section of the vertical elements varies from $1.0 \times 0.6$ to $1.1 \times 3.9 \mathrm{~m}$.

First, the following program of works was drawn up: study and analysis of process design and post-completion documentation, visual and instrumental inspection of the superstructure block of the foundation; development of a project design to strengthen the foundation constructions; development of a work order project to strengthen the foundation; vibrodiagnostics of the foundation state after strengthening.

In the course of the visual and instrumental inspection of the foundation, the following was detected:

1) oiling of the surface on the concrete areas of frames 3,4 and 5 with up to $50 \mathrm{~mm}$ depth of over $17 \%$ of the foundation surface;

2) a through crack up to $1 \mathrm{~mm}$ in width in the upper part of the pier of frame 2 adjacent to the plate; cracks in the longitudinal beam between frames 2 and 3, some of the cracks are covered with oil;

3 ) wreckage of the protective coat of the concrete and reinforcement corrosion are found in over $15 \%$ of the surface; 
4) measuring of the actual strength of concrete by nondestructive inspection techniques revealed that the strength of concrete is not even for all elements of the foundation and fluctuates between 119.7 and $335.7 \mathrm{~kg} / \mathrm{cm}^{2}$ (by scratching test) and between 107.5 and $292 \mathrm{~kg} / \mathrm{cm}^{2}$ (by ultrasound test), while the design value is $150 \mathrm{~kg} / \mathrm{cm}^{2}$;

5) constructions with incorrectly performed lift joints, areas of the foundation with poorly vibrated concrete, bare reinforcement without a protective concrete layer;

6) soaking of reinforced concrete constructions on $28 \%$ of the surface;

7) the works to asses the actual geometrical dimensions of the superstructure block of the foundation it was detected that deviations of actual dimensions of some elements of reinforced concrete constructions from the design position reach up to $76 \mathrm{~mm}$. It was also determined that skewness of separate vertical elements was $45 \mathrm{~mm}$.
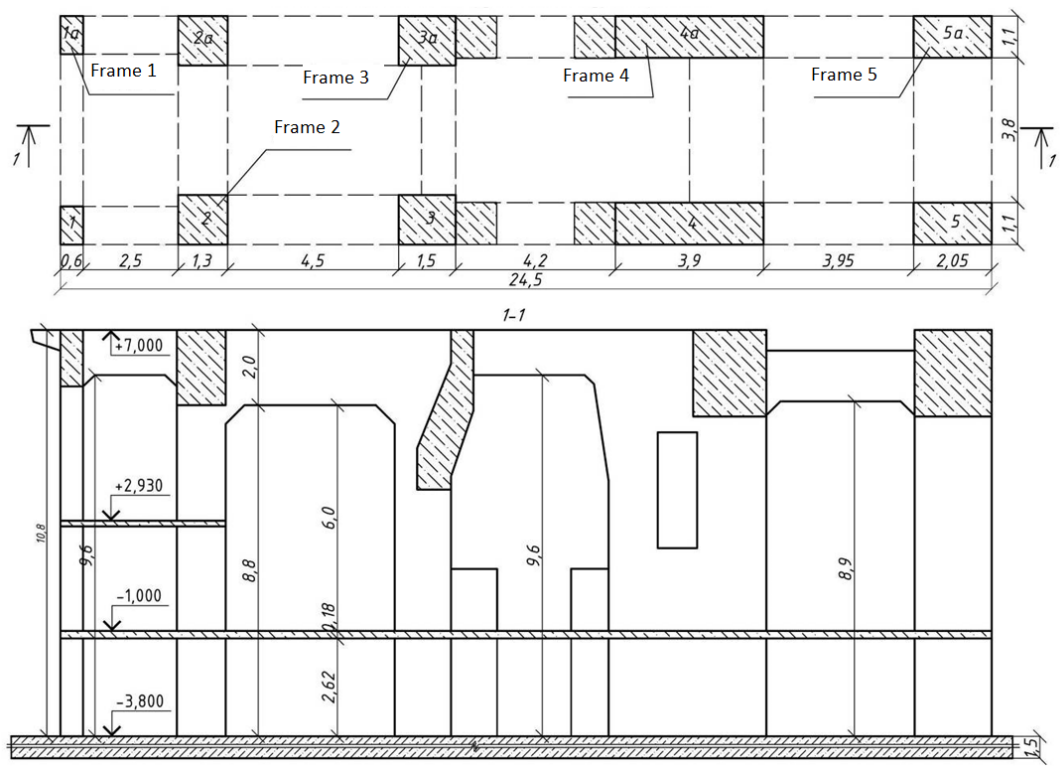

Fig. 1. Plan and cross-section of the superstructure block of the turbine-generator set foundation

Based on the data collected during the inspection, specialists of the SE "RIBP" developed a structural design and a work order project to strengthen the reinforced concrete foundation of Minsk HPS No.3 with metal casing 
and extra underpinned portal frames using sprayed-on plaster and composite materials.

Considering the significant height of the supporting structures (up to $6.2 \mathrm{~m}$ ), their vertical unevenness and a large number of defects therein, a new technology for conducting works to strengthen the supporting structures with casing was developed, as under such conditions, classical design and technology solutions could not be used ${ }^{3}$. The developed technology differed from classical ones in that it did not provide for tight adherence of metal casing to the edges of the strengthened supporting structures, and the clearance between the foundation planes and the outer side of the casing angles exceeded $20 \mathrm{~mm}$. The space between the post and the casing was filled with sprayed-on plaster, following which the whole surface was plastered and smoothed level with the upper edges of the casing angles.

\section{Experimental tests of design and technology solution for strengthening columns}

Besides, before the developed design and technology solution was introduced into the design documentation, a number of laboratory and iron bird experimental tests were conducted to confirm its feasibility and efficiency.

First, the operational concept provided for strengthening the supporting structures with external reinforcement, i.e. by gluing extra-strong carbon fibers ${ }^{4}$. So, to establish the dependence of the impact of technological factors on the compression breaking strength of the strengthened fragments of columns, a number of experimental tests was conducted to check the efficiency of this technology.

The main structural and technological and, per se, technological factors which can influence the efficiency of strengthening vertical load-bearing reinforced concrete structures are as follows:

- presence / absence of acute angles;

- foundation preparation (pre-coating of the surface);

- the method of gluing the reinforcement (fiber) to the construction.

${ }^{3}$ Савйовский В. В., Болотских О. Н. Ремонт и рекострукция гражданских зданий/ Савйовский В.В., Болотских О.Н. -Х.: Ватерпас, 1999. - 288 с. ;6. Савйовський В. В. Реконструкція будівель і споруд / В. В. Савйовський. - К.: Видавництво Ліра-К, 2018. $320 \mathrm{c}$.

${ }^{4}$ Овчинников И. И., Овчинников И.Г., Чесноков Г.В., Михалдыкин Е.С. Анализ экспериментальных исследований по усилению железобетонных конструкций полимерными композитными материалами. Часть 1. Отечественные эксперименты при статическом нагружении // Интернет-журнал «НАУКОВЕДЕНИЕ» Том 8, №3 (2016); Савйовський В. В. Підсилення залізобетонних балочних конструкцій зовнішнім армуванням/ В. В. Савйовський, О. С. Молодід, Н. О. Малець // Управління розвитком складних систем. - 2017. - № 29. - С. 198 - 204. 
Reinforced concrete lintels of 2 PB 10-1 type were used with the following characteristics: dimensions (length $\mathrm{x}$ width $\mathrm{x}$ height) $-1030 \mathrm{x} 120$ $\mathrm{x} 140$, concrete grade - C12/15. These beams were cut lengthwise into fragments $230 \mathrm{~mm}$ each.

The samples were reinforced by gluing unidirectional carbon fibers to all their lateral surfaces by wrapping.

Six series of experimental tests were planned:

- series 1 - no actions were performed with the control samples (no reinforcement was added) (fig. 2);

- series 2 - the samples' angles were rounded, their surface was precoated, a coat of glue was applied, in which carbon fiber was sunk, and an extra coat of glue was applied on top of the fiber;

- series 3 - the samples' angles were not rounded, their surface was pre-coated, a coat of glue was applied, in which carbon fiber was sunk, and an extra coat of glue was applied on top of the fiber;

- series 4 - the samples' angles were rounded, a coat of glue was applied, in which carbon fiber was sunk, and an extra coat of glue was applied on top of the fiber;

- series 5 - the samples' angles were rounded, a coat of glue was applied, in which the carbon fiber was sunk,

- series 6 - the samples' angles were rounded, carbon fiber impregnated with glue was glued to the surface.

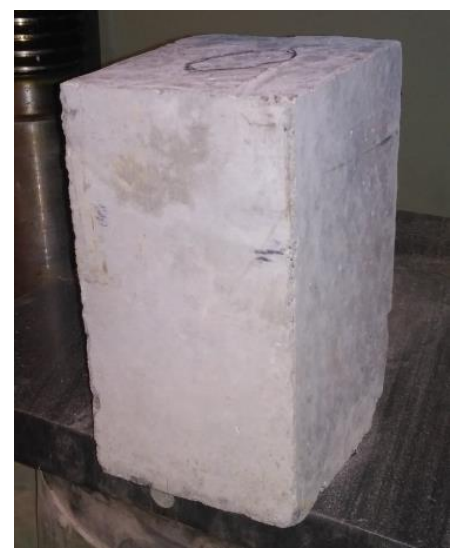

Fig. 2. Overall view of a nonreinforced sample

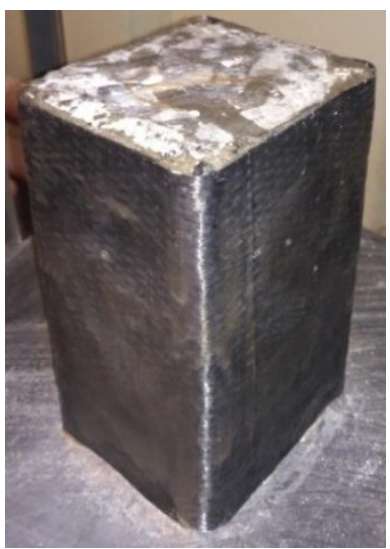

Fig. 3. Overall view of a reinforced sample 
Before carbon fibers was glued to the samples, their lateral surfaces were cleaned and pre-coated with Consolid-1 primer manufactured by COMPOSIT LLC, Kyiv (if provided for) ${ }^{5}$.

For the samples whose surface was pre-coated, further actions were taken at least in 24 hours. In other cases the fiber was glued immediately after the angles were rounded, the lateral surfaces were cleaned and dust removed therefrom.

EDMOK glue manufactured by COMPOSIT LLC, Kyiv was applied to the prepared surface, and strips of carbon fiber were sunk into the glue by a putty knife. In 5-10 minutes, another layer of EDMOK glue was applied on the surface so that it covered the whole surface.

In test series 6 carbon fiber was completely impregnated with glue in a special container, and then glued to the surface. It should be said that this way of gluing fibers to the surface increases the amount of glue almost 2 times in comparison with the method described above. Besides, when applying the fiber air pockets were formed under the fiber impregnated with glue, which were difficult to remove. Additional inconveniences included the need to drain the excess of the glue from the fiber and the fiber slipping off the construction.

The tests were conducted under the temperature $+(15-22){ }^{\circ} \mathrm{C}$ on $\mathrm{P}-125$ testing machine according to axial compression scheme 96 hours after external reinforcement had been glued. The loading was applied to the samples in $2000 \mathrm{~kg}$ steps. The tests were conducted until the complete demolition of the samples.

The experimental test results and fracture patterns of samples strengthened by various methods are displayed in table 1 .

The experimental tests analysis demonstrated that the highest bearing strength was reached on the samples of columns with rounded angles, where glue was applied on the basis of the sample and on carbon fiber (40.6 ton) (test series 4). The compression strength of such samples is $82.2 \%$ higher than that of the control samples (test series 1). Almost similar increase in strength, i.e., $81.7 \%$ as compared with the control samples, was achieved with the samples (test series 2), where besides the solutions used to strengthen the previous samples, the base was pre-coated. Analyzing the test results, we can state that the technological factor - pre-coating of sample surfaces before their reinforcement - does not increase strength, thus, it is impractical to perform this technological operation when strengthening columns.

\footnotetext{
5 Технологическая карта: на выполнение работ по восстановлению кирпичных, железобетонных конструкций и их защите. ООО «Композит». - К.: - 2009. - 7 с.
} 
Table 1

Experimental test results to determine the samples' breaking force

\begin{tabular}{|c|c|c|c|}
\hline $\begin{array}{c}\begin{array}{c}\text { No. of } \\
\text { test } \\
\text { series }\end{array} \\
\end{array}$ & $\begin{array}{c}\text { Average } \\
\text { breaking } \\
\text { force, tons }\end{array}$ & $\begin{array}{c}\text { Average } \\
\text { breaking } \\
\text { force, \% } \\
\end{array}$ & Sample fracture pattern (photo) \\
\hline 1 & 22.3 & 100 & \\
\hline 2 & 40.5 & 181.7 & \\
\hline 3 & 34.0 & 152.5 & \\
\hline 4 & 40.6 & 182.2 & \\
\hline 5 & 38.6 & 173.4 & \\
\hline 6 & 38.8 & 174.3 & \\
\hline
\end{tabular}

The compression strength of the strengthened samples in which the angles were not rounded (test series 3 ) was found to be the lowest, namely 
34.0 tons, which is $52.2 \%$ higher comparing with the control samples and $29.7 \%$ lower than the strength of test series 4 samples. It should be said that on such samples the carbon fiber tore at the angles, which can indicate that the fibers were cut by sharp sample angles, or, alternatively, that supernormal tension was created at the angles leading to fiber tearing in these places.

The results of experimental tests of sample series 6 demonstrated that their compression strength is $74.3 \%$ higher than that of the control samples ad $7.9 \%$ lower than the strength of test series 4 samples. It is worth mentioning that in real-life conditions of construction this technology is difficult to implement, as it has a number of disadvantages described above.

The compression strength of test series 5 samples is 38.6 tons, which is $73.4 \%$ higher than that of the control samples and $8.8 \%$ lower than the strength of test series 4 samples. This technology may be used in further research and in conducting similar works in construction, as the absence of the upper layer of glue cuts the manufacturing and labor costs, as well as the performance time.

At the next stage of experimental tests, the design and technology solutions were tried on sample columns. Here, it was planned to study certain solutions implemented at the previous stage and the solutions proposed to be included in the design documentation. Also, the efficiency of strengthening columns with a classical method, namely a metal casing with pre-stressed plates, was tested.

Reinforced concrete lintels of 2 PB 10-1 type were used with the following characteristics: dimensions (length $\mathrm{x}$ width $\mathrm{x}$ height) $-1030 \mathrm{x} 120$ $\mathrm{x} 140$, concrete grade $-\mathrm{C} 12 / 15$. Fragments were cut off of these ribs, leaving a rib $800 \mathrm{~mm}$ in length, with which further tests were conducted.

Seven series of experimental tests were planned (fig. 4, 5):

- series 1 - no actions were performed with the control samples (no reinforcement was added) (

- series 2 - the samples' angles were rounded, their surface was precoated, a coat of glue was applied, in which carbon fiber strips was sunk, and an extra coat of glue was applied on top of the fiber (the fiber was glued with the materials manufactured by COMPOSIT LLC);

- series 3 - the samples' angles were rounded, their surface was precoated, a coat of glue was applied, in which carbon fiber strips was sunk, and an extra coat of glue was applied on top of the fiber (the fiber was glued with the materials of MAPEI ${ }^{\mathrm{TM}}$ );

- series 4- metal casing with pre-stressed plates;

- series 5-metal casing at the distance of $10 \mathrm{~mm}$ along the perimeter from the column with further application of sprayed-on plaster, while the cavity pockets between the column angles and casing angles were filled; 
- series 6 - the samples' angles were rounded, their surface was precoated, a coat of glue was applied, in which polyethylene-terephthalate fiber was sunk, covering the whole surface, and an extra coat of glue was applied on top of the fiber (the fiber was glued with the materials manufactured by COMPOSIT LLC);

- series 7 - the samples' angles were rounded, their surface was precoated, a coat of glue was applied, in which the carbon fiber was sunk, covering the whole surface, and an extra coat of glue was applied on top of the fiber (the fiber was glued with the materials manufactured by COMPOSIT LLC).

The prepared samples were tested with the method used at the previous stage. The test results are presented in Table 2.

- The analysis of the experimental test results demonstrated that the highest bearing strength was reached on the samples of columns with full strengthening with carbon fibers (54.4 tons) (test series 7 ). The compression strength of such samples is $97.9 \%$ higher than that of the control samples (test series 1). The strength increase by $52.5 \%$ and $54.5 \%$ as compared with the control samples was reached in the samples with metal casing and plaster and samples strengthened with strips of carbon fiber glued with the materials manufactured by COMPOSIT LLC (test series 5 and 2). Strengthening columns using the classical technology (test series 4) increased its compression strength by $37.6 \%$ as compared with the control samples.
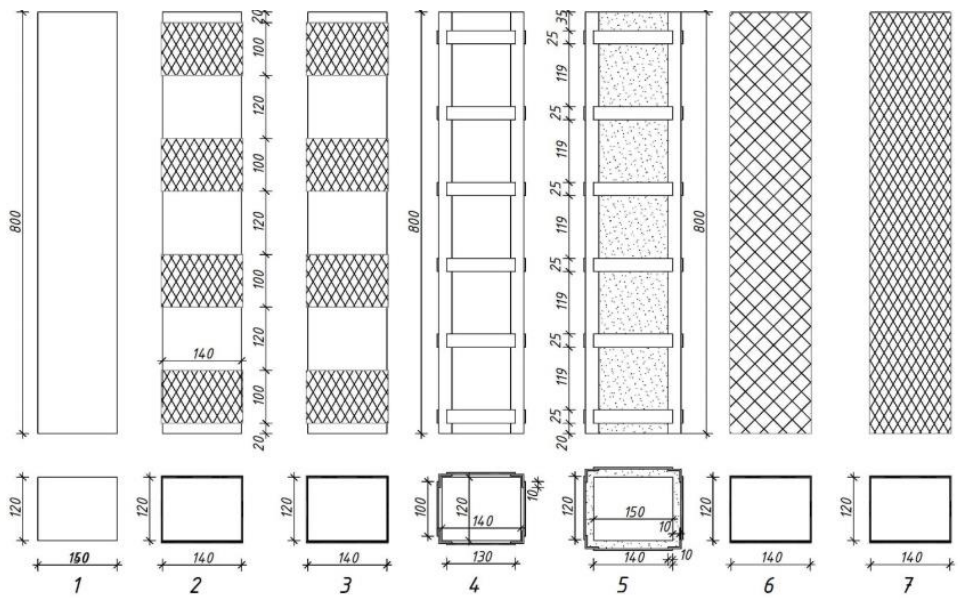

Fig. 4. Patterns of sample strengthening in test series 
Table 2

Experimental test results in determining breaking forces of columns

\begin{tabular}{|c|c|c|}
\hline No. of test series & Average breaking force, tons & Average breaking force, \% \\
\hline 1 & 27.5 & 100 \\
\hline 2 & 42.5 & 154.5 \\
\hline 3 & 32.7 & 118.9 \\
\hline 4 & 37.6 & 136.7 \\
\hline 5 & 46.6 & 152.5 \\
\hline 6 & 36.6 & 133.1 \\
\hline 7 & 54.4 & 197.9 \\
\hline
\end{tabular}

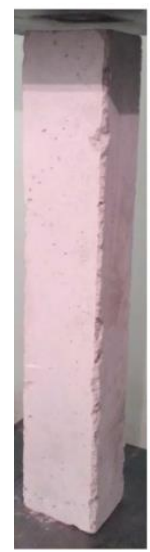

a

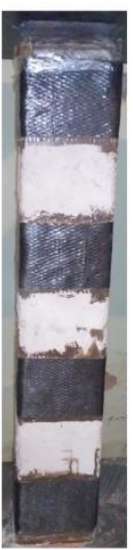

b

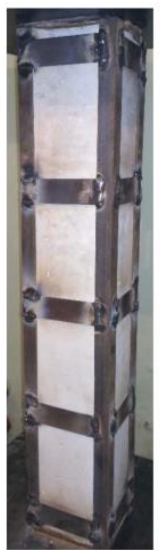

$\mathrm{c}$

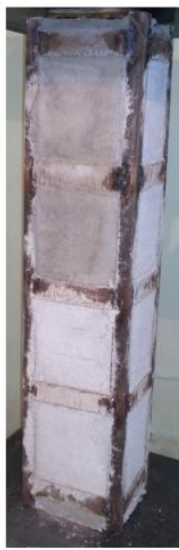

d

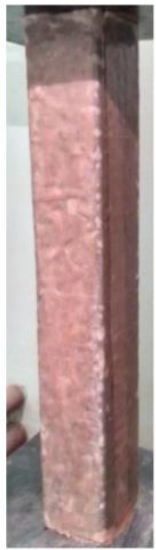

e

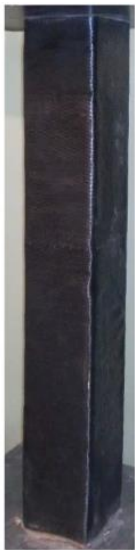

f

Fig. 5. General view of the tested columns:

$\mathrm{a}$ - not strengthened (series 1 ); $\mathrm{b}$ - strengthened with carbon fiber strips (series 2, 3); c-strengthened with metal casing with pre-stressed plates (series 4 ); $d$ - metal casing at a distance from the column with the cavity pocket filled with plaster (series 5); e - solid strengthening with polyethylene-terephthalate fabric (series 6); $\mathrm{f}$ - solid strengthening with carbon fabric (series 7)

Fracture of the tested column samples is displayed at fig. 6 


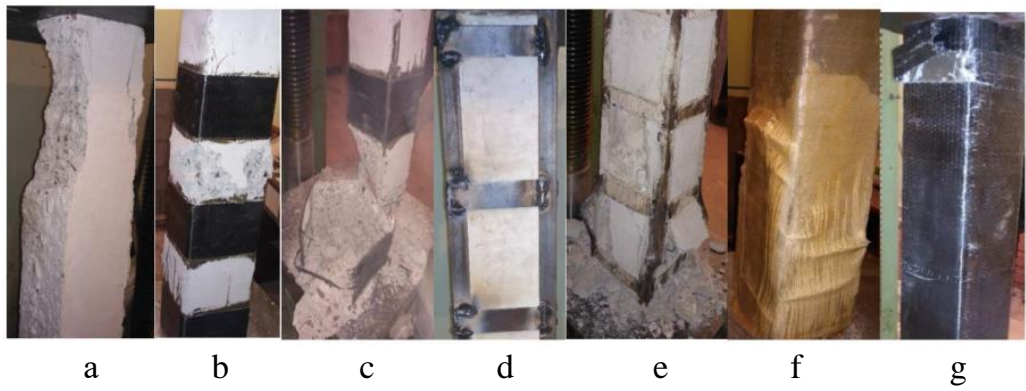

Fig. 6. General view of the columns after the tests:

$\mathrm{a}$ - not strengthened (series 1 ); $\mathrm{b}$ - strengthened with carbon fiber strips (series 2); c-strengthened with metal casing with pre-stressed plates (series 3);

$\mathrm{d}$ - strengthened with metal casing with pre-stressed plates (series 4); $\mathrm{e}$ - metal casing at a distance from the column with the cavity pocket filled with plaster (series 5); $\mathrm{f}$ - solid strengthening with polyethylene-terephthalate fabric (series 6); $\mathrm{g}$ - solid strengthening with carbon fabric (series 7)

The analysis of the data received in the course of the experimental tests leads to believe that the proposed design and technology solution for strengthening the foundation support structures where the metal casing is fixed at a certain distance from the support structure, and the space between the column and the casing is filled with spayed-on plaster, is an effective strengthening method, as it allows to increase the bearing strength of the support structures roughly by $50 \%$. The experimental test data show that the most effective solution is to strengthen the support structures with carbon fiber; however, the in-depth analysis of the permissible conditions for operational capacity of this method revealed that constructions strengthened with the use of epoxy-based glues cannot be operated at high temperatures. It is evident that temperature and humidity at HPS are always high, which is why the method of strengthening the support structures with carbon fiber glued with epoxy-based glue was not considered in the design documentation, although its efficiency significantly exceeds the efficiency of the rest of the methods.

The use of a specially developed design and technology solution for strengthening the support structures with the help of metal casing positioned at a certain distance from the column, where the space between the column and the casing is filled with spayed-on plaster mixture eliminated the need to preliminary straighten the lateral edges of the support structures and to repair concrete defects, which significantly decreased the work labor input and their duration. 


\section{Implementation of results of the experimental tests}

Before the strengthening of the turbine-generator foundation had been commenced, the impact of how constructions and technological equipment limited the spread of work and the conditions of performing the works was analyzed. Based on this analysis, the equipment and utility networks hindering the works on strengthening constructions were dismantled where possible; points of connecting tools and equipment with the existing energy supply networks were installed; a set of auxiliary measures was taken to ensure operational safety under the conditions of on-going operations and to protect the technological equipment, utility networks, materials and finished products from possible damage or contamination in the course of construction works.

Before the works were commenced, the working area was fenced with demountable hurdle with warning signs affixed to it.

The preparation included the following technological operations: installation of scaffolding, fixing of lifting tackles and fitting welder operators' platforms.

The strengthening of the vertical elements of foundation frames (support structures and columns) with metal casings on the first and second tear (at the height of $2.62 \mathrm{~m}$ and 5.2 and $6.2 \mathrm{~m}$ respectively) was carried out for the whole height in one operation. The angles were fitted and welded in pairs. First, the angles were located in the design position at the columns' angles so that the space between the plane of the column and the interior of the angles was not less than $20 \mathrm{~mm}$. The angles were fixed in this position by welding to each pair of angles of metal strips in four points throughout the whole height of the structure.

The comprehensive process of strengthening the support structures of the frames consisted of a number of simple processes: surface preparation, assembly of metal casing (fig. 7, a); application of Consolid-1 and Consolid-2 composite materials manufactured by COMPOSIT LLC; application of sprayed-on plaster (fig. 7, b).

The simple processes were completed in the following order: cleaning the foundation surface from dust, dirt, oil and bitumen stains; pulling of cracks; pre-coating of separate areas; application of repair polymer-cement mixtures in separate places; installation of the metal casing composed of angles, and of a part of connecting plates made of sheet metal and bearing blocks; pre-coating of the surface with two layers of Consolid-1 composite material; applying of one layer of Consolid-2 composite material; concrete spraying of the surface; welding of the remaining connecting plates, anti- 
corrosive protection of the welding connections; applying one layer of Consolid-1 composite material on the surface (fig. $7, \mathrm{c})^{6}$.

In this technology, Consolid-1 composite material was used to enhance the strength of the existing concrete of the foundation, and Consolid-2 - to enhance the strength of grip between the existing concrete constructions of the foundation with the subsequently applied layers. Polymer composite materials were applied by spraying on hard-to-reach areas and on the concrete under the casing, and by spreading on the open areas. The second layer of Consolid-1 was applied 18-24 hours after the first one; after that, a layer of Consolid-2 was applied by small portions onto the freshly applied layer of Consolid-1. During 2-4 hours, plaster mixture was applied onto the layer of Consolid-2. The time specifications for working with polymer compounds were adopted in accordance with the material manufacturer's recommendations.

Concrete spraying was completed from bottom up in tiers of 1.2-1.5 m for the whole width of the support constructions. First, the space between the planes of the existing construction and the inner side of the angles was filled with plaster, next - the space between the posts with angles. The plaster was applied in layers: the thickness of the first layer was $1 \mathrm{~cm}$, of the next layer 1.5-2.0 $\mathrm{cm}$ (up to the upper plane of the casing angles), with a 4-hour technological break between the time of applying the layers. The surface of the last plaster layers was smoothed and evened. In 18-20 days, the surface of the plaster and metal elements of the casing was covered with a layer of Consolid-1.

Separate horizontal constructions of the foundations, i.e. beams between frames 2 and 3, were strengthened by placing additional portal frames. An additional portal frame consists of 6 support structures with H-shaped crosssection placed on the first and second tiers. To evenly distribute the force, horizontal H-shaped beams were placed on the support structures of the first tier, whereupon the posts, together with the beams, were tightened to the bottom of the floor slab. This was achieved by screwing in bolts provided for in the bottom part of the support structures. The space between the foundation plate and the support structure plate was covered with concrete.

\footnotetext{
${ }^{6}$ Организация строительного производства: ТКП 45-1.03-161-2009. [Действующий с 2014-07-01]. - Минск: Минстройархитектуры Республики Беларусь 2014. - 48 с.; Технологическая документация при производстве строительно-монтажных работ. Состав, порядок разработки, согласования и утверждения технологических карт: ТКП 45-1.01159-2009 (02250). [Действующий с 2009-09-30]. - Минск: Минстройархитектуры Республики Беларусь 2009. - 16 с.
} 


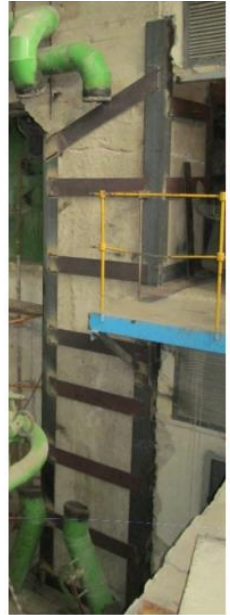

a

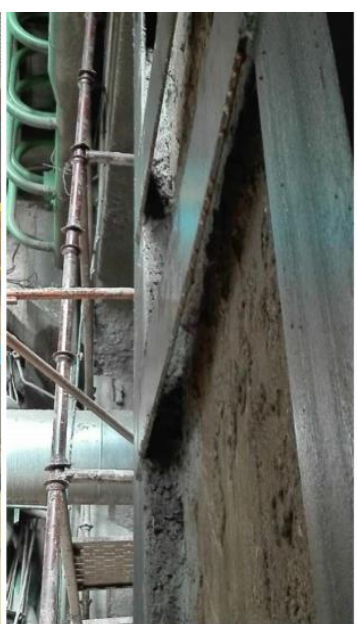

b

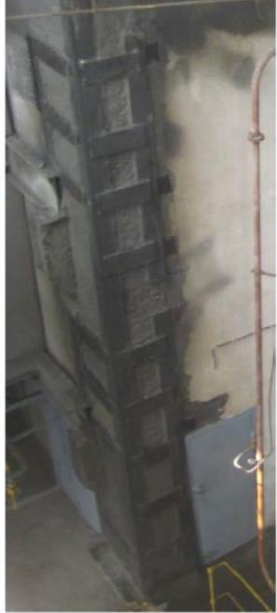

c

Fig. 7. Photos demonstrating the process of column strengthening: $\mathrm{a}$ - fitting of metal casings; $\mathrm{b}$ - filling cavity pockets between the column angles and casing angles with sprayed-on plaster; $\mathrm{c}$ - strengthened column

A month after the turbine-generator launch, both the level of vibration speed of the turbine and of the foundation was checked. The assessment demonstrated that the maximum recorded level of vibration speed reached $2.7 \mathrm{~mm} / \mathrm{s}$, with the standard indicator of $4.5 \mathrm{~m} / \mathrm{s}$.

\section{CONCLUSION}

A comprehensive approach to solving the problem of the strength and stability of the foundation constructions under the turbine-generator, which included visual and instrumental inspection of the foundation construction, development of a project design to strengthen the foundation constructions, development of a work order project to strengthen the foundation, made it possible to restore the designed bearing strength of the foundation.

The design and technology solutions for strengthening columns before they are used in the construction underwent experimental testing in laboratory and iron bird samples. Based on the test results, it was established that the proposed method allows to increase the bearing strength of the support structures roughly by $50 \%$. 
The repair and recovery works allowed to reach the level of vibration speed of $2.7 \mathrm{~mm} / \mathrm{s}$, which is 2.5 times lower of the vibration speed observed before the works were conducted $(6.8 \mathrm{~mm} / \mathrm{s})$.

\section{SUMMARY}

The article deals with a comprehensive approach to technical inspections of buildings and constructions and designing repair and restoration works, which is composed of the development of scientific research program, program modelling of the work of the construction or the whole building in real-life conditions, plotting dependences etc. Further, as needed, laboratory, iron bird (bed) and field tests with the modelling of the work of the repaired or restored construction or whole building in real-life conditions. Only then design documentation for repair and restoration works is developed.

This approach was tested on the foundation of the turbine-generator set of Minks HPS No. 3. In accordance with the developed program, the following works were conducted: study and analysis of process design and post-completion documentation, visual and instrumental inspection of the superstructure block of the foundation; development of a project design to strengthen the foundation constructions; development of a work order project to strengthen the foundation; vibrodiagnostics of the foundation state after strengthening. Based on the data collected during the inspection, structural design and a work order project were developed to strengthen the reinforced concrete foundation with metal casing and extra underpinned portal frames using sprayed-on plaster and composite materials. The peculiar feature of the developed technology was that the casing angles were adjusted at the distance not less than $20 \mathrm{~mm}$ from the angles of the strengthened posts, and the space between the metal casing and the reinforced concrete construction was filled with sand-cement mixture by spraying.

Besides, before the developed design and technology solution was introduced into the design documentation, a number of laboratory and iron bird experimental tests were conducted to confirm its feasibility and efficiency.

The analysis of the data received in the course of the experimental tests leads to believe that the proposed design and technology solution for strengthening the foundation support structures is an effective strengthening method, as it allows to increase the bearing strength of the support structures roughly by $50 \%$. 
The repair and recovery works allowed to reach the level of vibration speed of $2.7 \mathrm{~mm} / \mathrm{s}$, which is 2.5 times lower of the vibration speed observed before the works were conducted $(6.8 \mathrm{~mm} / \mathrm{s})$.

\section{REFERENCES}

1. ДСТУ-Н Б В.1.2-18:2016 Настанова щодо обстеження будівель і споруд для визначення та оцінки їх технічного стану. - Київ: ДП «УкрНДНЦ», 2017. - 47 с.

2. Методические указания по обследованию фундаментов турбоагрегатов: РД 34.21.323-95. - М.: РАО «ЕЭС России», 1995. - 32 с.

3. ДСТУ Б В.3.1-2:2016. Ремонт і підсилення несучих i огороджувальних будівельних конструкцій та основ будівель і споруд [Чинний від 2017-04-01]. - Київ: ДП «УкрНДНЦ», 2017. - 72 с.

4. Беляков Ю. И. Романушко Е. Г. Запорожченко С. А. Средства механизации при реконструкции промышленных предприятий/ Беляков Ю. И. Романушко Е. Г. Запорожченко С. А. - К.: Будівельник, 1987. $144 \mathrm{c}$.

5. Савйовский В. В., Болотских О. Н. Ремонт и реконструкция гражданских зданий/ Савйовский В.В., Болотских О.Н. -Х.: Ватерпас, 1999. - $288 \mathrm{c}$.

6. Савйовський В. В. Реконструкція будівель i споруд / В. В. Савйовський. - К.: Видавництво Ліра-К, 2018. - 320 с.

7. Овчинников И. И., Овчинников И.Г., Чесноков Г.В., Михалдыкин Е.С. Анализ экспериментальных исследований по усилению железобетонных конструкций полимерными композитными материалами. Часть 1. Отечественные эксперименты при статическом нагружении // Интернет-журнал «НАУКОВЕДЕНИЕ» Том 8, № 3 (2016).

8. Савйовський В. В. Підсилення залізобетонних балочних конструкцій зовнішнім армуванням/ В. В. Савйовський, О. С. Молодід, Н. О. Малець // Управління розвитком складних систем. - 2017. № 29. - C. 198 - 204.

9. Технологическая карта: на выполнение работ по восстановлению кирпичных, железобетонных конструкций и их защите. ООО «Композит». - К.: - 2009. -7 c.

10. Организация строительного производства: ТКП 45-1.03-1612009. [Действующий с 2014-07-01]. - Минск: Минстройархитектуры Республики Беларусь 2014. - 48 с. 
11. Технологическая документация при производстве строительномонтажных работ. Состав, порядок разработки, согласования и утверждения технологических карт: ТКП 45-1.01-159-2009 (02250). [Действующий с 2009-09-30]. - Минск: Минстройархитектуры Республики Беларусь 2009. - 16 с.

\section{Information about the author:}

Molodid O. S.,

Ph.D. in Engineering, Associate Professor, Assistant Professor at the Construction Production Technology Department, Kyiv National University of Construction and Architecture 31, Povitroflotskyi Ave., Kyiv, 03037, Ukraine 